
6 Kingdom

7

\section{Abstract}

\title{
A comparative phylogenomic analysis of peste des petits ruminants virus isolated from
} wild and unusual hosts

\author{
Aziz-ul-Rahman ${ }^{1 *}$, Muhammad Munir ${ }^{2}$, Muhammad Zubair Shabbir ${ }^{1}$
}

${ }^{1}$ University of Veterinary and Animal Sciences, Lahore 54600, Pakistan

${ }^{2}$ Division of Biomedical and Life Sciences, Lancaster University, Lancaster LA1 4YG United

\section{*Corresponding author: drazizangel@,gmail.com; https://orcid.org/0000-0002-3342-4462}

Running title: Comparative phylogenomic analysis of peste des petits ruminants virus

Peste des petits ruminants virus (PPRV) infects a wide range of domestic and wild ruminants, and occasionally unusual hosts such as camel, cattle and pig. Given their broad host-spectrum and disease endemicity in several developing countries, it is imperative to elucidate the viral evolutionary insights for their dynamic pathobiology and differential host-selection. For this purpose, a dataset of all available ( $n=37$ ) PPRV sequences originating from wild and unusual hosts was composed and in silico analysed. Compared to domestic small ruminant strains of same geographical region, phylogenomic and residue analysis of PPRV sequences originating from wild and unusual hosts revealed a close relationship between strains. A lack of obvious difference among the studied sequences and deduced residues suggests that these are the host factors that may play a role in their susceptibility to PPRV infection, immune response, pathogenesis, excretion patterns and potential clinical signs or resistance to clinical disease. Summarizing together, the comparative analysis enhances our understanding towards molecular epidemiology of the PPRV in wild and unusual hosts for appropriate intervention strategies particularly at livestock-wildlife interface.

Key words: Peste des petits ruminants virus; wild and unusual hosts; molecular epidemiology; residue comparison; phylogenomic analysis 
Peste des petits ruminants (PPR) caused by peste des petits ruminants virus (PPRV) [1], is an

OIE enlisted notifiable disease of domestic and wild ruminants that can spread across international borders [2]. Belong to genus Morbillivirus within the family Paramyxoviridae, PPRV also has potential to infect a wide range of susceptible host as is the characteristic of other morbillliviruses especially canine distemper virus (CDV) and rinderpest virus (RPV). Both viruses can potentially infect a wide range of susceptible hosts including wildlife, large ruminants, rodents and monkeys [3, 4]. Since, PPRV is closely related to CDV and RPV, and PPRV infection evidences have been reported in small ruminants, large ruminants, camel, wildlife species and pig $[5,6]$. The potential of pig to act as virus amplifier and to shed virus in the environment indicates their role in the disease spread to small ruminants and other susceptible hosts [6].

The virus carries a negative sense, single stranded RNA genome of approximately $16 \mathrm{~kb}$ encoding six structural proteins; nucleocapsid $(\mathrm{N})$, phosphoprotein $(\mathrm{P})$, matrix $(\mathrm{M})$, fusion (F), hemagglutinin (H) and polymerase (L) in an order of $3^{\prime}-\mathrm{N}-\mathrm{P}-\mathrm{M}-\mathrm{F}-\mathrm{H}-\mathrm{L}-5^{\prime}$ [7]. The $\mathrm{N}$ protein is involved in ribonucleoprotein complex (RNP) formation for RNA encapsidation during viral transcription, replication and assembly. Together with $\mathrm{P}$ and $\mathrm{L}, \mathrm{N}$ protein acts as a polymerase co-factor, which governs the virus replication [8]. Various domains and motifs in the $\mathrm{N}$ protein reduce the replication fitness of virus and thus carry potential to generate attenuated vaccine candidates from virulent field strains. Together with extensive use of $\mathrm{N}$ genes (due to transcriptional potential) and protein (due to transcription-gradient translation) in the detection of viruses using qualitative reverse-transcriptase polymerase chain reaction (qRT-PCRs) and enzyme linked immunosorbent assay (ELISA), respectively, greater and comparative assessments of the $\mathrm{N}$ protein are imperative. On the other hands, the $\mathrm{H}$ glycoprotein plays a prime role in tissue tropism by binding to two cellular receptors known 
as poliovirus receptor-like 4 (Nectin-4) and signalling lymphocyte activation molecule (SLAM) [9, 10]. The SLAM receptors (also known as CD150 molecules) are immunoglobulin (Ig) superfamily glycoproteins and are expressed on the surface of many immune cells including primary B cells, virus-transformed B cells (B95a), T cells (activated, memory and clonal), and immature thymocytes [11]. The localization of these receptors determines host adaptation and correlates with virus-induced pathologies [9]. The $\mathrm{H}$ glycoprotein recognizes and uses overlapping regions to bind to these cellular receptors (SLAM and Nectin-4), which elicits conformational changes in the attachment protein to reveal a trigger sequence in its stem region that interact with the globular head of the fusion protein [12]. Taken together, these receptors are likely a major hurdle for morbilliviruses to cross the species-barrier and eventually require mutations in the receptor-binding regions of the $\mathrm{H}$ protein for host adaptation [12]. While extensive information has been made available on the $\mathrm{H}$ proteins, cellular factors that govern viral interactions with receptors in hostdependent manners are lacking. Understanding of these factors may highlight the virus jumps between hosts, and can explain the potential preference of the virus for specific hosts. PPR is considered endemic in the Middle East, Africa and Asia. Four distinct lineages (I, II, geographical patterns [13]. Utilizing complete genome or partial gene sequencing (e.g. $N$ gene), comparative molecular epidemiology and genetic variability of PPRVs in domestic small ruminants have widely been assessed in disease-endemic regions [14, 15]. Nevertheless, there is paucity on the phylogenetic relationship of PPRVs originating from wildlife and unusual hosts. Therefore, the current study was designed to explore genetic markers that allow an interpretation whether certain PPRV strains are more likely to be transmitted or disseminated from domestic to wild/unusual hosts or vice versa. Cumulative 
outcome may facilitate the devising of appropriate intervention strategies particularly at livestock-wildlife interface for effective disease control in disease-endemic countries.

\section{Materials and Methods}

There is a paucity of genome sequence data for PPRV reported from wild and unusual hosts in public databases (http://www.ncbi.nlm.nih.gov/, accessed by June 2019). The available data is limited to five complete genome sequence and two complete and 30 partial nucleoprotein $(N)$ gene sequences originating from various wild and unusual hosts. Therefore, selective data $(\mathrm{n}=102)$ including $N$ partial gene sequences of PPRVs from unusual and wild hosts origin $(\mathrm{n}=37)$ and domestic small ruminants origin $(\mathrm{n}=65)$ representing different lineages were used in this study. The sequences were aligned using ClustalW method in BioEdit ${ }^{\circledR}$ version 5.0.6 [16] and edited to equal length. To assess the phylogeny patterns, a tree was constructed using distance-based neighbour-joining model in MEGA $^{\circledR}$ version 6.0 where reliability in topology of tree was assured with bootstrap replications $(1,000)$ and $p$-distance substitution model [17]. The deduced amino acid sequences of complete $N, H$ and $F$ genes from wild and unusual hosts $(\mathrm{n}=6)$-origin PPRV were also compared with a strain originating from domestic small ruminants to determine substitution rations across the length of gene. To better elucidate a presumptive role of substitutions in host adaptation in wildlife or unusual hosts, sequences that were reported from domestic small ruminants during the same time period and geographical area were used in the analysis.

\section{Results and discussion}

Besides several important biological activities such as attachment, replication and induction of protective immune response in the host [13, 18, 19], the partial $N, F$ and $H$ genes sequences have been employed in a number of studies to determine the phylogeny and evolutionary relationship among circulating isolates worldwide [15, 18, 19]. Nonetheless, we 
used only partial $N$ gene sequences due to the fact that i) complete gene sequences for $N, F$ and $H$ genes were limited to a total of five isolates only and, when compared with corresponding genes originating from domestic small ruminants, their evolutionary relationship and deduced residue pattern was much alike, ii) a higher number of partial $N$ gene sequences originating from diverse species are available in public database, and iii) the sequence and residue characteristics provide a distinctive resolution for PPRV epidemiology in disease endemic countries $[13,15]$.

Phylogenetic analysis clustered wild and unusual hosts-origin PPRV strains into five distinct clades. However, direct comparison of these PPRV with strains from small ruminants suggested their common origin. Clade-I included the camel-originated (Sudan origin) and wild-alpine goat-originated (Morocco origin) viruses that clustered close to domestic small ruminant-origin strains reported from Sudan and Morocco. Clade-II included cattle-, dog-and Asiatic lion- originated (India origin) PPRV strains that clustered together with small ruminant's originated viruses from India. Clade-III comprised of wild goat-originated (Iraq origin), Ibex-originated (Israel origin) and biting midges-originated (Turkey origin) strains that clustered with domestic small ruminants-originated PPRV strains isolated in Iran, Iraq and Turkey. Sequences from camel (Pakistan) and bharal (China) origin were included in clade-IV and clustered with small ruminants-originated strains isolated in Tibet, China and Pakistan. Likewise, PPRV isolates from ibex (UAE and China), antelope (India), wild goat (Iran) and camel (Pakistan) origin made together clade- $\mathrm{V}$ and clustered with domestic small ruminant-originated strains isolated in China, Iraq and Pakistan (Fig. 1).

The phylogenetic analysis revealed a close relationship between strains recovered from domestic and wild/unusual hosts of the same geographical region. For instance, cameloriginated strains from Pakistan clustered close enough to those of domestic origin PPR viruses reported previously from Pakistan, Tibet and China. In disease endemic countries, the 
virus can easily transmit from one animal to another due to sharing a common source of water, food and vicinity or frequent contact particularly in areas where there are lack of welldefinite borders. Thus, it is not surprising that there is a close relationship between viruses isolated from different host species in the same geographical area, likely reflecting a spillover from domestic animals to wildlife [20-22]. A few of such evidences include disease outbreaks in Saudi Arabia [20], gazelle in UAE [21], ibex in Pakistan [22], bharal in Tibet [23], and water-deer in China [24]. Additionally, due to extensive animal movements such as in the Himalayas and Pamir region between Pakistan, Nepal, China, Afghanistan and Tajikistan, potential inter-species transmission with a closely related virus is not unusual [25]. Also, there are few studies where sero-conversion in wild and unusual host while living in close vicinity with domestic small ruminants has been reported [26, 27]. Although, the frequent contact between domestic and non-domestic animals may play a crucial role in the spread of virus, factors involved in the epidemiology of the PPRV at livestock-wildlife interface is largely unknown.

In contrast to identification of PPRVs of all lineages (I-IV) in domestic small ruminants in disease-endemic countries, viruses of only lineages II, III and IV have been reported to-date from wild or unusual host and camels [Table 1;28]. Usually, the lineage IV viruses were predominantly found affecting a wide range of wild and unusual hosts in disease-endemic countries. While the factors that predispose wildlife to lineage IV are not well defined, the wider distribution of lineage IV and its potential to cause pathologies in small ruminants are potential survival factors. Primarily, the lineage IV is the most dominant group of PPRV in disease-endemic countries [22-25] and this dominance further supports its distribution in susceptible hosts including wild and unusual animal species.

We have also conducted a comparative residue analysis of available complete $N, F$ and $H$ gene of PPRV originating from wild and unusual hosts and domestic small ruminants because 
residue substitutions in specific protein or a site leads to genetic variations either due to natural selection or adaptation to a novel host [29]. The deduced residues for $H$ gene (1-610 aa), particularly the N-terminal proximal anchor $\left({ }^{35}\right.$ PYILLGVLLVMFLSLIGLLAIAG $\left.{ }^{58}\right)$ and SLAM binding site $\left({ }^{529} \mathrm{Y},{ }^{530} \mathrm{D},{ }^{533} \mathrm{R},{ }^{552} \mathrm{~F},{ }^{553} \mathrm{Y},{ }^{554} \mathrm{P}\right)$ were observed in a pattern similar to those of domestic small ruminants [14]. Although, SLAM receptors have significance for host adaptation however, the conserveness of its binding motif in $H$ gene sequences obtained from PPRV-infected domestic and wildlife species indicated a lack of specific mutations that could be associated with the susceptibility of infection to a particular species, conclusively [30]. An influence on host adaptability and pathogenicity has previously been speculated upon the mutations/substitutions in $H$ gene [19], the gained outcome should be cautiously interpreted because of limitation of sequences $(n=6)$ available in the database. Interestingly, both the conservancy of SLAM binding motif and phylogenetic relationship of studied PPRVs strains to those of their respective host species (sheep and goats) anticipated that all these strains most likely evolved from a common ancestral virus indicating its intrinsic capacity to adapt novel host species [31].

The deduced residues across the whole length of $F$ gene (1-547 aa) particularly the signal peptide $\left({ }^{1}\right.$ MTRVAILAFLFLFLNAVAC $\left.{ }^{19}\right)$, the cleavage site $\left({ }^{103}\right.$ RRTRR $\left.^{108}\right)$, the fusion peptide $\left({ }^{109}\right.$ FAGAVLAGVALGVATAAQITAGVAL $\left.{ }^{133}\right)$, and the leucine zipper domain $\left({ }^{459}\right.$ LGNAVTRLENAKELLDASDASDQIL $\left.{ }^{480}\right)$ were found conserved. On the other hand, the nuclear export signal $\left({ }^{4} \operatorname{LLKSLALF}^{11}\right)$, nuclear localization signal $\left({ }^{70} \mathrm{TGVMISML}^{77}\right)$ and RNA binding motif $\left({ }^{324}\right.$ FSAGAYPLLWSYAMG $\left.{ }^{338}\right)$ were conserved for $N$ gene (1-526 aa). However, several substitutions were observed in the C-terminal regions of $N$ gene and, therefore, could be considered as a hypervariable region without having any significant role in host adaptation reported so-far [14]. Substitutions at position $444(\mathrm{~T} / \mathrm{S} \rightarrow \mathrm{P} / \mathrm{S}), 446(\mathrm{P} \rightarrow \mathrm{Q})$, $464(\mathrm{~S} \rightarrow \mathrm{G} / \mathrm{I}), 505(\mathrm{~L} / \mathrm{F} \rightarrow \mathrm{P} / \mathrm{F} / \mathrm{S}), 510(\mathrm{~S} \rightarrow \mathrm{P}), 516(\mathrm{~S} \rightarrow \mathrm{P})$ and $517(\mathrm{~K} \rightarrow \mathrm{E})$ were consistent for 
wild and unusual host than those reported for domestic small ruminants (Table 1). Although, the C-terminus of $\mathrm{N}$ protein is considered an important region for viral replication and substitutions in this region may have influence in the enhancement of persistency of virus infection for a long period [8], however, such substitutions have not influenced host adaptation. Based on the genomic similarities between PPRV sequences from small ruminant, camel and unusual host origin, the current study suggested that PPRV is promiscuous between host species without genomic alterations that may otherwise be required for adaptation to novel host/s. Though genomic and residue substitutions may have an influence on the evolution and adaptation of other morbilliviruses to novel hosts [31], however, it was not observed for PPRV in the current study.

\section{Conclusion}

The study provides an understanding towards the phylogenomics and evolutionary relationships among PPRV strains originating from domestic and wild/unusual hosts. Comparative genomic and residue analysis revealed a close relationship between study PPRV strains reported from the same geographical region. Since study data was limited to few of publically available sequences so far, there needs an abundant sequence dataset representing wild and unusual hosts to better elucidate underlying mechanisms on viral evolution in future. Most importantly, besides comparative sequence analysis, emphasis should be given to a range of host factors that may predispose adaptability and subsequent susceptibility of novel host to PPRV infection.

\section{Author's contribution}

AR, MZS apprehended the idea: AR, MM, MZS conceived and designed the work; AR, MZS did data analysis; AR, MM, MZS edited final draft.

\section{Acknowledgment}

None 
Ethical approval: This article does not contain studies with animals or humans performed.

Informed consent: No human or animals were involved.

\section{Figure captions}

Fig. 1 Phylogenetic analysis of 102 partial $N$ gene nucleotide sequences (255bp) reported for

PPRV. Black circle indicates the isolates reported from wild and unusual animals. Green

207

208

colour of branches and isolates name indicate lineage IV while, blue indicates lineage II,

Fuchsia indicates lineage I, and red indicates lineage III.

\section{References}

1. Amarasinghe GK, Bào Y, Basler CF, Bavari S, Beer M, Bejerman N, Blasdell KR, Bochnowski A, Briese T, Bukreyev A, Calisher CH (2017) Taxonomy of the order Mononegavirales: update 2017. Arch Virol 1;162(8):2493-504.

2. Baron MD, Diallo A, Lancelot R, Libeau G (2016) Peste des petits ruminants virus. In Advances in virus research Vol. 95:1-42 Academic Press.

3. Kock RA, Wamwayi HM, Rossiter PB, Libeau G, Wambwa E, Okori J,Shiferaw FS, Mlengeya TD (2006) Re-infection of wildlife populations with rinderpest virus on the periphery of the Somali ecosystem in East Africa. Prev Vet Med 75:63-80

4. Martinez-Gutierrez M, Ruiz-Saenz J (2016) Diversity of susceptible hosts in canine distemper virus infection: a systematic review and data synthesis. BMC Vet Res 12(1):78.

5. Aziz-ul-Rahman, Wensman JJ, Abubakar M, Shabbir MZ, Rossiter P (2018) Peste des petits ruminants in wild ungulates. Trop Anima Health and Prod 50(8):1815-9.

6. Schulz C, Fast C, Schlottau K, Hoffmann B, Beer M (2018) Neglected hosts of small ruminant morbillivirus. Emerg Infect Dis 24(12):2334.

7. Diallo A (1990) Morbillivirus group: genome organisation and proteins. Vet Microbiol 23(1-4):155-63

8. Heinrich BS, Morin B, Rahmeh AA, Whelan SP (2012) Structural properties of the C terminus of vesicular stomatitis virus $\mathrm{N}$ protein dictate N-RNA complex assembly, encapsidation, and RNA synthesis. J Virol 86(16):8720-9.

9. Adombi CM, Lelenta M, Lamien CE, Shamaki D, Koffi YM, Traoré A, Silber R, Couacy-Hymann E, Bodjo SC, Djaman JA, Luckins AG (2011) Monkey CV1 cell line expressing the sheep-goat SLAM protein: a highly sensitive cell line for the isolation of peste des petits ruminants virus from pathological specimens. J Virol Methods 173(2):306-13.

10. Fakri F, Elarkam A, Daouam S, Tadlaoui K, Fassi-Fihri O, Richardson CD, Elharrak M (2016) VeroNectin-4 is a highly sensitive cell line that can be used for the isolation and titration of Peste des Petits Ruminants virus. J Virol Methods 228:135-9.

11. Tangye SG, Phillips JH, Lanier LL, Nichols KE (2000) Functional requirement for SAP in 2B4-mediated activation of human natural killer cells as revealed by the Xlinked lymphoproliferatic syndrome. J Immunol 165;2932-2936. 
12. Lin LT, Richardson C (2016) The host cell receptors for measles virus and their interaction with the viral hemagglutinin $(\mathrm{H})$ protein. Viruses8(9):250.

13. Parida S, Muniraju M, Mahapatra M, Muthuchelvan D, Buczkowski H, Banyard AC (2015) Peste des petits ruminants. Vet Microbiol 181(1-2):90-106

14. Balamurugan V, Sen A, Venkatesan G, Yadav V, Bhanot V, Riyesh T, Bhanuprakash V, Singh RK (2010) Sequence and phylogenetic analyses of the structural genes of virulent isolates and vaccine strains of peste des petits ruminants virus from India. Transbound Emerg Dis 57(5):352-64

15. Muniraju M, Munir M, Parthiban AR, Banyard AC, Bao J, Wang Z, Ayebazibwe C, Ayelet G, El Harrak M, Mahapatra M, Libeau G (2014) Molecular evolution of peste des petits ruminants virus. Emerg linfect Dis 20(12):2023

16. Hall TA (1999) BioEdit: a user-friendly biological sequence alignment editor and analysis program for Windows 95/98/NT. InNucleic acids symposium series (Vol 41:95-98). [London]: Information Retrieval Ltd., c1979-c2000. http://jwbrown.mbio.ncsu.edu/JWB/papers/1999Hall1.pdf

17. Tamura K, Stecher G, Peterson D, Filipski A, Kumar S (2013) MEGA6: molecular evolutionary genetics analysis version 6.0. Mol Bio Evol 30(12):2725-9

18. Liang Z, Yuan R, Chen L, Zhu X, Dou Y (2016) Molecular evolution and characterization of hemagglutinin $(\mathrm{H})$ in peste des petits ruminants virus. PloS One 11(4):e0152587

19. Sahu AR, Wani SA, Saminathan M, Rajak KK, Sahoo AP, Pandey A, Saxena S, Kanchan S, Tiwari AK, Mishra B, Muthuchelvan D (2017) Genome sequencing of an Indian peste des petits ruminants virus isolate, Izatnagar/94, and its implications for virus diversity, divergence and phylogeography. Arch Virol 162(6):1677-93

20. Furley CW, Taylor WP, Obi TU (1987) An outbreak of peste des petits ruminants in a zoological collection. The Vet Rec 121(19):443-7

21. Kinne J, Kreutzer R, Kreutzer M, Wernery U, Wohlsein P (2010) Peste des petits ruminants in Arabian wildlife. Epidemiol Infect 138(8):1211-4

22. Abubakar M, Rajput ZI, Arshed MJ, Sarwar G, Ali Q (2011) Evidence of peste des petits ruminants virus (PPRV) infection in Sindh Ibex (Capra aegagrus blythi) in Pakistan as confirmed by detection of antigen and antibody. Trop Ani Health Prod 43(4):745-7

23. Bao J, Wang Z, Li L, Wu X, Sang P, Wu G, Ding G, Suo L, Liu C, Wang J, Zhao W (2011) Detection and genetic characterization of peste des petits ruminants virus in free-living bharals (Pseudois nayaur) in Tibet, China. Res Vet Sci 90(2):238-40

24. Zhou XY, Wang Y, Zhu J, Miao QH, Zhu LQ, Zhan SH, Wang GJ, Liu GQ (2018) First report of peste des petits ruminants virus lineage II in Hydropotes inermis, China. Transbound Emerg Dis 65(1):e205-9 http://onlinelibrary.wiley.com/doi/10.1111/tbed.12683/epdf

25. Banyard AC, Parida S (2015) Chapter 5: Molecular Epidemiology of Peste des Petits Ruminants Virus. In: Munir M, (eds) Peste des Petits Ruminants Virus 69-93. Springer, Berlin, Heidelberg. https://doi.org/10.1007/97836624516565

26. Mahapatra M, Sayalel K, Muniraju M, Eblate E, Fyumagwa R, Shilinde S, MaulidMdaki M, Keyyu J, Parida S, Kock R (2015) Spillover of peste des petits ruminants virus from domestic to wild ruminants in the serengeti ecosystem, Tanzania. Emerg Infect Dis 21(12):2230

27. Marashi M, Masoudi S, Moghadam MK, Modirrousta H, Marashi M, Parvizifar M, Dargi M, Saljooghian M, Homan F, Hoffmann B, Schulz C (2017) Peste des Petits Ruminants Virus in Vulnerable Wild Small Ruminants, Iran, 2014-2016. Emerg Infect Dis 23(4):704 
28. El-Hakim OA (2006) An Outbreak of Peste de Petit Ruminants (PPR) At Aswan Province, Eygpt-Evaluation of Some Novel Tools for Diagnosis Of PPR. Assiut Vet Med J 52(110):132-145

29. Denison MR, Graham RL, Donaldson EF, Eckerle LD, Baric RS (2011) Coronaviruses: an RNA proofreading machine regulates replication fidelity and diversity. RNA biology 8(2):270-9

30. Bae CW, Lee JB, Park SY, Song CS, Lee NH, Seo KH, Kang YS, Park CK, Choi IS (2013) Deduced sequences of the membrane fusion and attachment proteins of canine distemper viruses isolated from dogs and wild animals in Korea. Virus Genes 47(1):56-65

31. Jo WK, Osterhaus AD, Ludlow M (2018) Transmission of morbilliviruses within and among marine mammal species. Curr Opin Virol 28:133-4 
Table 1 Comparative residue analysis of partial $N$ genes of PPRV isolated from various wild and unusual hosts (available until June, 2019).

\begin{tabular}{|c|c|c|c|c|c|c|c|c|c|c|c|c|}
\hline \multirow{2}{*}{ Lineage } & \multirow{2}{*}{ Country } & \multirow{2}{*}{ Host } & \multirow{2}{*}{$\begin{array}{l}\text { Source of } \\
\text { isolation }\end{array}$} & \multirow{2}{*}{$\begin{array}{c}\text { Year of } \\
\text { isolation }\end{array}$} & \multirow{2}{*}{$\begin{array}{c}\text { Accession } \\
\text { number }\end{array}$} & \multicolumn{7}{|c|}{ Residue positions at $\mathrm{C}$-terminus } \\
\hline & & & & & & 444 & 446 & 464 & 505 & 510 & 516 & 517 \\
\hline \multirow{43}{*}{ IV } & \multirow{6}{*}{ India } & Goat & Tissue & 2008 & GQ122189* & $\mathbf{T}$ & $\mathbf{P}$ & $\mathbf{S}$ & $\mathbf{L}$ & $\mathbf{S}$ & $\mathbf{S}$ & $\mathbf{K}$ \\
\hline & & Chousingha & Tissue & 2013 & KY914553" & - & - & - & - & - & - & - \\
\hline & & Cattle & Nasal swab & 2007 & EF641263 & $\mathbf{P}$ & $\mathbf{Q}$ & $\mathbf{G}$ & $\mathbf{P}$ & $\mathbf{P}$ & $\mathbf{P}$ & $\mathbf{E}$ \\
\hline & & Dog & Nasal swab & 2015 & KT120060 & $\mathbf{P}$ & $\mathbf{Q}$ & $\mathbf{G}$ & $\mathbf{P}$ & $\mathbf{P}$ & $\mathbf{P}$ & $\mathbf{E}$ \\
\hline & & Asiatic lion & Tissue & 2007 & JN632530 & $\mathbf{P}$ & $\mathbf{Q}$ & $\mathbf{G}$ & $\mathbf{P}$ & $\mathbf{P}$ & $\mathbf{P}$ & $\mathbf{E}$ \\
\hline & & Asiatic lion & Tissue & 2007 & JN632532* & $\mathbf{P}$ & $\mathbf{Q}$ & G & $\mathbf{P}$ & $\mathbf{P}$ & $\mathbf{P}$ & $\mathbf{E}$ \\
\hline & \multirow{5}{*}{ Pakistan } & Goat & Nasal swab & 2012 & KJ398330! & $T$ & $\mathbf{P}$ & $\mathrm{S}$ & $\mathbf{L}$ & $\mathrm{S}$ & $\mathrm{S}$ & $\mathrm{K}$ \\
\hline & & Camel & Blood & 2012 & KC207882 & $\mathbf{S}$ & $\mathbf{Q}$ & - & $\mathbf{F}$ & - & - & - \\
\hline & & Camel & Blood & 2012 & KC207883 & $\mathbf{S}$ & $\mathbf{Q}$ & - & $\mathbf{F}$ & - & - & - \\
\hline & & Camel & Blood & 2012 & KC207884 & $\mathbf{S}$ & $\mathbf{Q}$ & - & $\mathbf{F}$ & - & - & - \\
\hline & & Camel & Blood & 2012 & KC207885 & $\mathbf{S}$ & $\mathbf{Q}$ & - & $\mathbf{F}$ & - & - & - \\
\hline & \multirow{9}{*}{ China } & Goat & Nasal swab & 2014 & MF443354! & $T$ & $\mathrm{P}$ & $\mathbf{S}$ & $\mathbf{L}$ & $\mathrm{S}$ & $\mathrm{S}$ & $\mathrm{K}$ \\
\hline & & Siberian ibex & Tissue & 2014 & KX664096" & $\mathbf{S}$ & - & - & - & - & - & - \\
\hline & & Siberian ibex & $\begin{array}{c}\text { Nasal-anal } \\
\text { swab }\end{array}$ & 2014 & KX664098" & $\mathbf{S}$ & - & - & - & - & - & - \\
\hline & & Siberian ibex & Tissue & 2016 & KX664100" & $\mathbf{S}$ & - & - & - & - & - & - \\
\hline & & $\begin{array}{l}\text { Goitered } \\
\text { gazelle }\end{array}$ & $\begin{array}{c}\text { Nasal-anal } \\
\text { swab }\end{array}$ & 2016 & KX664097" & $\mathbf{S}$ & - & - & - & - & - & - \\
\hline & & Argali & Tissue & 2015 & KX664099" & $\mathbf{P}$ & - & - & $F$ & - & - & - \\
\hline & & Ibex & Tissue & 2015 & KT633939**t & $\mathbf{S}$ & - & - & - & - & - & - \\
\hline & & Wild bharal & Tissue & 2008 & $\mathrm{JX} 217850^{* *+!}$ & $\mathbf{P}$ & - & - & $\mathbf{F}$ & - & - & - \\
\hline & & Wild bharal & Tissue & 2008 & EU815054! & $\mathbf{P}$ & - & - & $\mathbf{F}$ & - & - & - \\
\hline & \multirow{12}{*}{ Sudan } & Sheep & Tissue & 2008 & HQ131931! & $\mathrm{P}$ & $\mathbf{P}$ & $\mathrm{S}$ & $\mathrm{L}$ & $\mathrm{S}$ & $\mathrm{S}$ & $\mathrm{K}$ \\
\hline & & Camel & Tissue & 2005 & HQ131934 & - & $\mathbf{Q}$ & - & - & - & - & - \\
\hline & & Camel & Tissue & 2004 & HQ131935 & - & $\mathbf{Q}$ & - & - & - & - & - \\
\hline & & Camel & Tissue & 2007 & HQ131936 & - & $\mathbf{Q}$ & - & - & - & - & - \\
\hline & & Camel & Tissue & 2006 & HQ131937 & - & $\mathbf{Q}$ & - & - & - & - & - \\
\hline & & Camel & Tissue & 2006 & HQ131938 & - & $\mathbf{Q}$ & - & - & - & - & - \\
\hline & & Camel & Tissue & 2005 & HQ131939 & - & $\mathbf{Q}$ & - & - & - & - & - \\
\hline & & Camel & Tissue & 2007 & HQ131940 & - & $\mathbf{Q}$ & - & - & - & - & - \\
\hline & & Camel & Tissue & 2007 & HQ131941 & - & $\mathbf{Q}$ & - & - & - & - & - \\
\hline & & Camel & Tissue & 2008 & HQ131942 & - & $\mathbf{Q}$ & - & - & - & - & - \\
\hline & & Camel & Tissue & 2004 & HQ131947 & - & $\mathbf{Q}$ & - & - & - & - & - \\
\hline & & Camel & Tissue & 2005 & HQ131948 & - & $\mathbf{Q}$ & - & - & - & - & - \\
\hline & \multirow{2}{*}{ Iraq } & Sheep & Nasal swab & 2013 & KF992797! & $\mathbf{S}$ & $\mathbf{P}$ & $\mathrm{S}$ & $\mathrm{L}$ & $\mathrm{S}$ & $\mathrm{S}$ & $\mathrm{K}$ \\
\hline & & Wild goat & Nasal swab & 2011 & JF969755 & $\mathbf{P}$ & $\mathbf{Q}$ & - & - & - & - & - \\
\hline & \multirow{2}{*}{ Morocco } & Goat & Not available & 2015 & KY885100 & $\mathrm{P}$ & $\mathrm{Q}$ & $\mathrm{S}$ & $\mathbf{F}$ & $\mathrm{S}$ & $\mathrm{S}$ & $\mathrm{K}$ \\
\hline & & Alpine goat & Nasal swab & 2008 & KC594074**! & - & - & - & $\mathbf{S}$ & - & - & - \\
\hline & \multirow{2}{*}{ UAE } & Sheep & Nasal swab & 2013 & KF992797! & $\mathrm{S}$ & $\mathrm{P}$ & $\mathbf{S}$ & $\mathrm{L}$ & $\mathrm{S}$ & $\mathrm{S}$ & $\mathrm{K}$ \\
\hline & & Ibex & Tissue & 2009 & FJ795511 & - & - & I & - & - & - & - \\
\hline & \multirow{2}{*}{ Israel } & Goat & Nasal swab & 2016 & DQ840191" & $T$ & $\mathrm{P}$ & $\mathbf{S}$ & $\mathrm{L}$ & $\mathrm{S}$ & $S$ & $\mathrm{~K}$ \\
\hline & & Nubian ibex & Tissue & 2017 & MF678816**! & $\mathbf{P}$ & - & - & - & - & - & - \\
\hline & \multirow{3}{*}{ Turkey } & Lamb & Nasal swab & 2016 & MG744248 & $\mathrm{S}$ & $\mathrm{P}$ & $\mathrm{S}$ & $\mathrm{L}$ & $\mathrm{S}$ & $\mathrm{S}$ & $\mathrm{K}$ \\
\hline & & $\begin{array}{c}\text { Biting } \\
\text { midges }\end{array}$ & Tissue & 2015 & KU325483 & - & - & - & - & - & - & - \\
\hline & & $\begin{array}{l}\text { Biting } \\
\text { midges }\end{array}$ & Tissue & 2015 & KU175171 & - & - & - & - & - & - & - \\
\hline \multirow{2}{*}{ III } & UAF & Goat & Nasal swab & 1986 & DQ840169" & $\mathrm{P}$ & $\mathrm{P}$ & $\mathrm{S}$ & $\mathrm{P}$ & $\mathrm{T}$ & $\mathrm{S}$ & $\mathrm{T}$ \\
\hline & & Gazelle & Tissue & 1986 & KJ867545**! & - & - & - & - & - & - & - \\
\hline II & China & $\begin{array}{l}\text { Vaccine } \\
\text { strain }\end{array}$ & Not available & 1975 & X74443 & $\mathrm{P}$ & $\mathrm{P}$ & $\mathrm{S}$ & $\mathrm{L}$ & $\mathrm{S}$ & $\mathrm{S}$ & K \\
\hline & & Water deer & Tissue & 2016 & KY196465*! & - & - & - & - & - & - & - \\
\hline
\end{tabular}

Note: The domestic small ruminants originating PPRV isolates used for comparison were selected according the highest similarity to PPRV strains originating form wild/unusual hosts representing same geographical region and year of isolation. Random substitutions in individual isolate were also observed. Substitutions are bold in grey highlighted boxes. Identical residue denoted by " “ " ..+ = Isolation of virus from swabs and tissues samples from animal representing clinical infection, whereas except are the sequences of strain from apparently healthy animals.Abbreviations: T: Threonine, P: Proline, S: Serine, L: Leucine, K: Lysine, Q: Glutamine, F: Phenylalanine, P: Proline, E: Glutamic acid, I: Isoleucine, G: Glycine ${ }^{*}$ Complete genome sequence is available; ${ }^{*}$ Complete $N$ gene sequence is available 